\title{
Sustainability of Performance-Based Contract in Indonesia National Road
}

\author{
Hanie Teki Tjendani $^{\# 1}$, Nadjadji Anwar ${ }^{\# 2}$, I Putu Artama Wiguna ${ }^{\# 3}$ \\ \# 1,2,3 Department of Civil Engineering, \\ Institut Teknologi Sepuluh Nopember (ITS) Surabaya 60111, Indonesia \\ ${ }^{1}$ hanie_tekitjendani@yahoo.com ; ${ }^{2}$ nadjadji@gmail.com ; ${ }^{3}$ artama.wiguna@gmail.com
}

\begin{abstract}
A performance-based contract was applied the past 7 years in Indonesia, as an effort to create a fair and optimal risk sharing between the government and private sector. Performance-based contracts could potentially give rise to various benefits to the road management, contractor and road user. The benefit of the application of PBC is the declining cost, especially life cycle cost, ensuring the road handling and road performance. This indicates that the financial aspect and performance of the services can be a major consideration for a switch from the application of the traditional approach to the PBC. In addition to the benefits of the economic aspects, the success of PBC also determined from various aspects that influence each other, namely the social aspect and environmental aspects. This paper analyses the sustainability of PBC implementation that suits the Indonesian national road management system based on literature review. Sustainability of implementing PBC in Indonesia should pay attention to the main effort to success PBC, namely: long-term contract, a degree of freedom of the contractor in innovation, a balanced risk among owner and private sector, fairness reward and punishment, developing robust models to optimize maintenance strategies, increase database of specified the road network, maintain performance level before implementing long-term PBC. And must be able to resist the influence of high political effect, weak implementation of law rule.
\end{abstract}

Keyword-delivery system, performance-based contract, risk sharing, national road

\section{INTRODUCTION}

Indonesia is attempting to answer the key challenges to the construction and maintenance of the infrastructure networks that are essential to the economic stability. Aging infrastructures, cost escalation, limited resources, productivity, acute regional development, environmental issues, and sprawling growth are causing concern to the management and administration of infrastructure networks. Presently, the delivery of national road projects generally adopts the Design, Bid, Build (DBB) system.

Two legal of state government can be combined in construction project procurement, there are the Law of Indonesian Government No. 18, 1999 on Construction Services Regulation and Indonesian Government Regulation No. 29, 2000 on Construction Service Implementation. This represents that a Design-Build (DB) delivery system, in which design, construction stages are integrated into one contract, is a satisfactory form that acknowledges and possible for an achievement to get the better of the defect of DBB delivery systems of Indonesia road infrastructure.

Even though "degrees of freedom" sometimes failed in some of the Design-Build (DB) contracts, their apply may more be rational. As the road authority takes the lengthy term cost, they have an encouraging to safe that the selected fulfillment doesn't follow with large costs for operations and maintenance. The next reason could be that the road authority would want to get clean up of the design risk without awarding the contractor any probability to stray from the basic resolution of how to build. A wisdom that is trusted to upgrade the rapidity of innovation and the degree of productivity to move on from Design-bid-build contracts (DBB) to Design-Build contracts (DB). In the other word that set the contractor increasing degrees of freedom to bring through innovation. The supposition is composed of two stage, first that DB really has more "degrees of freedom" and secondly that more "degrees of freedom" cause to more innovation".[1]

That's why in spite of the fact that the DBB approach holds to be fair to the contractors, it is recognized as not able to produced profit for the infrastructure owner. Particularly, its long procurement duration frequently outputs in bad condition including work delays and increased cost. For the time being, Design, Build, Operate and Maintenance (DBOM) or Performance based contract (PBC) are being studied in several pilot projects [2]. Such as another integrated contracts, a performance-base contract can give guidance to increasingly sustainable infrastructure expansion by reason of the life-cycle optimization stimulus given of the related contract phase of design, construction, and maintenance. Especially to follow more sustainable infrastructure expansion [3]. 
The study focuses the sustainability and development of PBC contracts in Indonesia. This paper discussion based on a literature study. The main purpose of this paper is to look into the reference implementation of performance-based contracts to be implemented in Indonesia. The existing literature stated that this contract brings many advantages including cost savings and risk sharing to the party that caused the risk. Or risk transfer to the party that is able to take risks. and the PBC implementation is benefits for road users because it produced an outcome of increased level of a service road.

\section{LITERATURE REVIEW}

\subsection{Conventional Contracting Problems}

In the conventional contracting method, road authority choose the planning consultants and contractors to executing the work through a competitive procurement. Developing countries have faced problems at the end of the maintenance period the contractor due to routine maintenance and periodic maintenance is a responsibility of road authority which was done by in-house labor based on the unit price.Maintenance is not just on the surface of the road but in the effort to preserve roads, bridges and other facilities. The road condition is very bad that caused a budget increase in road authority to improve the road performance. A single rehabilitation project is estimated to cost three to four times the amount that should be spent on routine and periodic road maintenance.In developing countries, the road authority desperation related to many factors involved in decision making. This is particularly, in the task of great road maintenance projects in growing countries where a lot of organizations like external funding authorities and consultants are complex [4]. Occasionally, it is hard to create the proper resolution for the road owner in growing countries as there are many responsive decision-making factors involved.

The frequent complication observed in conventional method of road maintenance contract from the literature are time and cost overrun, bad quality of work and a low ability of contractors, an insufficient encouragement of contractors, no real risk sharing among the road authority and the third party, overhead and inspection cost, delayed of project accomplishment, a substantial degree of political affect and graft and deficiency of knowledge of the PBCs in the public sector. The conventional contracting method based on quantitative input and output do not enough handling all sustainability requirement. The linear infrastructures projects are not evaluated in implementation by any equipment system to their sustainability [5].

\subsection{Performance-Based Contract}

A performance-based contract (PBC) bear the meaning for suitable outputs and outcomes within an agreed time setting. The innovative contract for the process of maintaining a road, this contract in which the action of paying for the management and maintenance are clearly related to the contractor become successful fulfill minimum performance indicators, at least condition of road, bridge and traffic assets that have to be fulfilled by the contractor. To each of the reasons for the development to the specifications result of work are the develop into something in the future for cost saving, transferring risk and prepare the contractor to use an effective and efficient innovation to provide the best performance result. The advantages of PBC was integrated contract for a long period of time, lump sum payment contracts and using performance criteria or level of service. Five key characteristics of a PBC: (1) needs concentrates based on the contractual outcomes, not the quantity, and not how the work is carried out, (2) arrange of indicators involved to the outcomes, (3) accomplishable performance reputable for each indicator, (4) establish process to accumulate, analyze and notify data for the chosen indicator, (5) field of monetary and non-monetary consequences, either rewards or punishments for the contractor, based on performance indicator achievement. [6]

The Performance-Based Contracts (PBC) has been distinguished as contract method that efficient resolving the limitations of the conventional contracting methods. Disparate the conventional method, in PBC the contractor is normally free to build the resolutions along described performance standard are accomplished. This going to assign to allocate the authority of finishing the contract with its risk of collapse totally to the contractors. It has been questioned for contractors to profitable operate the entire risk of projects especially with little resources, little understanding of PBC, require of skillful staff, and bad management. In addition, inapplicable of accurate pavement condition prediction models to find out and forecast pavement performance results in a bigger risk to the contractor in PBC.The main elements of the developed scheme involve: growing a solid database of detailed expertise of the road network, growing practical models to forecast this moment and future conditions of the pavement, and growing strong models to optimize maintenance strategies [7]. Considering the kind of risks imprescriptible in meeting a performance requirement, it is necessary for a private sector to possess an obvious view of this risks, such as a reason for allocation with them in the procurement and contracting of the project [8]. PBCs is a delivery system insusceptible to corruption than the conventional ones. This is because a no negotiation embroiled so that the inspection is easier, the level of service (LOS) could be formed the masses and establish that the motoring public is can recognize if contractual fulfillment is being met. [9] 
The successful applications of PBC have also been observed in many other developed and developing countries. Some research identifies cost saving until $20 \%$ in an implementation of the performance-based contract, there is detecting that the pay off PBC delivery system would save $20 \%$ better VFM (value for money) than the conventional contract. Such as in Regional Transport Authority, NSW Tasmania Western Australia has $10 \%$ to $35 \%$ cost saving. Finnish Road Enterprise 7\% to $10 \%$ cost saving for contract period 3 years and 13\% cost saving for contract period 7 years. New Zealand has $20 \%$ cost saving for 10 years contract period. Alberta Canada has $5 \%$ cost saving for the first contract and $25 \%-35 \%$ for the second contract. Another success country for the applications PBC is Guatemala, Peru, Brazil, Columbia, Chile, Uruguay, Australia, USA and started before the 2000s.[9]

Some state is starting to be aware and profit by these outcome-based criteria in the maintenance contract. Maintenance must be carried out in deciding the adequate or proper levels so that there is neither cost increase or low road conditions. The outcome based pavement standard are roughness (IRI), rutting, skid resistance, deflection, cracking. The principal elements in the PBC was risks. If the great deal risk is assigned to the contractor, the cost might be increased and if a too small number of risk are transferred may not much profit to the road owner. Risks can be revealed in the contract agreement be due to criteria of work too high, deficiency of competitor, lack of documentation or benchmark data, an untrained contractor in PBC delivery system, lack of supply chain management and other varied. The road owner or road administrator require to a suitable expert in the assignment of risk in PBC.[10] Such as another integrated contracts, a performance-base contract can give guidance to increasingly sustainable infrastructure expansion by reason of the life-cycle optimization stimulus given of the related contract phase of design, construction, and maintenance.[3]

To enhance the gain of $\mathrm{PBC}$, the threat that department of transportation around the world include the distribution of risks to the part that can manage the risks best. There must be a good relationship as work team "partnering" among stakeholder. A further problem is recognition and interpretation of proper performance indicators. The challenge on implementation PBC in Indonesia such as overloading, the quality of existing pavement and the finance capacity of the Ministry of Finance for a long term contract.[2]. Indonesia also initiated PBC pilot projects in 2011 the Pantura Section Ciasem-Pamanukan $(18.5 \mathrm{~km})$ in West Java Province, section Demak-Trengguli (7.68 kilometers) in Central Java Province. The next pilot project in 2012, Section Semarang - Bawen $(22 \mathrm{~km})$ in Central Java Province, section Bojonegoro - Padangan (11 kilometers) and section Padangan - Ngawi $(10.7 \mathrm{~km})$ in East Java Province. The last pilot project in 2013, section Sei Hanyu Tumbang Lahung $(50.60 \mathrm{~km})$ in Central Kalimantan Province. All sections are categorized as national roads. The contract duration of these projects is 4 until 7 years. [2][11]

The experience of Australia, when people looking for greatest benefit of money, removing all or greatest risk to the non-government contractor are impossible or unsuitable. This also the problem in Indonesia. Infrastructure builder firm does not own ability on technical and financial to keep hold of high risks, in additional, the unpredictability in Indonesian is more great and complicated, due to high political effect in the regional and state aim and weak implementation of law rule. Consequently, it should be better in control and manage the risk. Detailed of risk such as the challenge of PBC implementation it was thinking about the ministry of the fund was improbable to accept funding proposal of multi-year road conservation contract until they could make sure of the excellence result and benefit. In addition, PBC is a prospective system to stimulate private sectors to expend money with the expectation of future in heavy equipment while operating in remote areas as the capital's return will be more secure and more advantage can be hoped. PBC is more compatible for locations where the road's shape is not too bad. For much defective roads is recommended to begin with a rehabilitation program based on a DBB (design-bid-build) delivery system.[2].

\subsection{Various Issues in Implementing PBC}

There are some problem which need special interest during the execution of PBC in a growing country. The problem is as follows: political effect, fraudulence against state finances, keep the of long-term funding, and calculating the estimation cost of PBC. Effect of relating to the government or the public affairs of a leaders and parties in the road sector is a serious affair for growing countries. One of the aim of introducing PBMC for road construction maintenance is to reduce the chance of political impact and corruption [4].

Pilot project a performance-based contract implementation in Nepal begun in 2003. The road performance based on the structure of expense efficiency, a level of service gain and excellent of service. Unfortunately, the execution of $\mathrm{PBC}$ was not effectual in Nepal as road asset maintenance. The excuse is poor service performance of contractor and poor contract execution from the road agency. [12]

Based on the research in Texas, on the whole, a performance-based contract is a contract that can attend a goal for any region. The best outcome in a larger region that have a way into local capable contractors. Restricting the contract to specials roadways or region is an indicate to supervise costs whilst attend to the features of a top attention. As usually, the greater contract in scope or longer duration will exclusively set a preferable worth to the road authority than a little contract and short duration of a contract. [13]. 
In UK, the road authority must determine whether to look for innovation from the request side or the provider side. If a lot of belief is positioned on public sector clients who might insufficiency the in-house experience to establish innovative request, this might yield in extreme expense on consultants, as well as superfluous risk transfer. Request-led innovation and provider-led innovation implicate important risks on both parts of the dealings. Such purchase should not be seen as a sure cure, but as innovative expansion to procurement that is necessaries to be respected very accurately across a range of aspects. [14]

In Sweden, potential factors contributing to PBC productivity are; apply long-term contracts (as much as possible), apply great areas of economic scale, combine of servicing of economic scope, a balanced risk sharing among road authority and private sector, possessing innovative and sophisticated equipment, fairness of application reward and punishment, more degree of freedom and flexibility of the contractors, using partnering, measuring the performance of the maintenance contractors, applying Technology Information system that is flexible and easy to use. The successful of implementation PBC differs from one country and another. what is successfully done in one country may not be successful in another country, due to cultural differences. Possessing a tidy and efficient maintenance organization surely, affect productivity, but is especially in conditional on the contractor's prepare and practices. This needs a knowledge and learning process and might not be accompanied by the novice road authorities and those owning traditional ways to asset maintenance. In essentially, establishing surroundings of occasion and structure for success can have a positive effect on the productivity.[15]

Enforcement of PBMC in the roads sector in Nigeria has the good potency to:

increasing economic activity due to make better road circumstances, cost saving which could be continuation to the development the road network and road facilities, invest transparency in the superintendence and preservation of the road network, gain road-user satisfaction and level of service of national road. However necessary to : carry out requirement road sector reforms and looking for road preservation fund, states also need to carry out similar reforms as part owners of the national road network, adopt and learning from another country the experience and success implementation PBMC.[16]

For refinement in Malaysian Construction Industry, delivery system and financial may be used as PBC is leading to take advantages in its practice. Awareness is the key for construction employees. To get over the challenges in Malaysian construction industry, it is important for authority to boost new procurement that suits the projects to fix their performance. [17].

The expand of network require the recognition of many benchmarks to good purpose carry out pavement conditions in the Emirate of Abu Dhabi. The major parts of the expanded network embrace 1) a rise database of specified the road network, 2) expanding method to forecast the future conditions of the pavement and 3) growing robust models to make optimization of strategies.[7]

Furthermore, the road authority of a growing state should make sure that the selection of contractors will be without political effect. This matter is not become an attention in developed countries as their road authorities are always ambitious to make sure road users pleasure and gain the tax payers money in the form of safe and secure roads. Many growing countries have obtain donation and moneylending from international institution during the practice of PBC. Even though, the road authority should not be contingent only on the outer support. They should attempt to control and arrange internal finance for multi-year PBC as soon as possible. The road owner in growing countries may face questions in estimation the cost of PBC due to deficiency of existing data on roads. They should arrange a multi-year planning before inaugurate PBC such as: starting the project with the highway for which information and history are accessible and in the mean and doing research in similar consent in other growing state.

\section{III.METHODOLOGY}

This study analyzed the literature that has been produced by previous authors on performance-based contracts. In this paper show continuity between previous studies and how it relates to current research. As well as integrating and conclude things that are known in the study area, learn from others and stimulate new ideas.

As an early stage, this paper composed the formulation the problem and then the problems must be written in full and proper. This was followed by literature searching, among others, searching the literature relevant to the research, get research topics overview, sources from supported research topics by a knowledge that studied, sources that provide an overview/summary of previous research. After getting adequate literature, do evaluate the data that display all contributed to any of the covered topics, search and find the appropriate data sources as needed to support research, the data is can be qualitative data, the quantitative data is or data derived from the combination of both. Analyze and interpret is the last step that contains activities to find a concise the literature review. While Techniques to perform the literature review are: search similarity (comparing), search inequality (contrast), give the view (criticize), compare (synthesize) and summary (summarize). 
Meanwhile, to get the source of literature can be found at paper publications and national or international journalized of a scientific nature and express a profound new knowledge gained through research, a high-level scientific writing for demonstrates the fact discovery and analysis methods based writer who can be retained truth, journals, conference proceedings results.

\section{IV.RESULTS AND DISCUSSION}

Best level of service of road infrastructure system for transportation is essential to preserve a sustainable socio-economic structure. In growing country, PBC is a conception recently developed to find a solution the problems related to a conventional method of a delivery system and has significant prospect to make better the maintenance and management of road infrastructure system. Developed countries including Australia, United Kingdom, United Arab Emirate, the Countries in United states of America, Sweden have carried out PBC successfully. Many growing countries such as Nigeria, Nepal, Malaysia, Indonesia have already realized PBC, where another are currently in consideration of PBC for their road infrastructure systems. The great number of literature and published information to in attendance at an overview of the prospective issues to be considered before the introduction of PBC in a country. This concept has a big potential of reducing road preservation cost, get larger the quality of works and make smaller the chance of political influence and corruption in the growing countries are the challenging issues for PBC, which needs more attention. It necessary to research performance level in different countries and to develop a model which can advise the road owner to plan with an appropriate performance-based maintenance contract and cost saving of road maintenance works. Risk management concept also have been suggested for the best practice, there is still required of organized approaches to explaining the synergy among social, technical, economic, environmental and political (STEEP) risks with consideration to all complicated and dynamic conditions of integrated construction for better appreciation and effective management of the management mechanism in terms of the nature risks, including their dynamic interactions and impacts in integrated development project.

TABLE I The Main Success PBC implementation in Developed Country

\begin{tabular}{|c|l|c|c|c|c|c|c|}
\hline \multirow{2}{*}{ Num } & \multicolumn{2}{|c|}{ Main Efford } & \multicolumn{5}{c|}{ Countries } \\
\cline { 3 - 7 } & & Australia & UK & Texas & Sweden & UAE & Indonesia \\
\hline 1 & Long term contract & $\mathrm{V}$ & & $\mathrm{V}$ & $\mathrm{V}$ & & $\mathrm{X}$ \\
\hline 2 & Degree of freedom & & & $\mathrm{V}$ & & $\mathrm{X}$ \\
\hline 3 & $\begin{array}{l}\text { A balance risk among the owner } \\
\text { and private sector }\end{array}$ & & $\mathrm{V}$ & & $\mathrm{V}$ & & $\mathrm{X}$ \\
\hline 4 & Fairness reward and punishment & & & & $\mathrm{V}$ & & $\mathrm{X}$ \\
\hline 5 & $\begin{array}{l}\text { Developing robust models to } \\
\text { optimize maintenance strategies }\end{array}$ & & & & & $\mathrm{V}$ & $\mathrm{X}$ \\
\hline 6 & $\begin{array}{l}\text { Increase database of specified the } \\
\text { road network }\end{array}$ & & & & & $\mathrm{V}$ & $\mathrm{X}$ \\
\hline 7 & $\begin{array}{l}\text { maintain performance level } \\
\text { before implementing long-term } \\
\text { PBC }\end{array}$ & $\mathrm{V}$ & & & & & $\mathrm{X}$ \\
\hline
\end{tabular}

Table 1, shows the effort of the developed country to sustain PBC. It is organized the synergy among social, technical, economic, environmental and political. However, caused by various obstacles has not been fully implemented in Indonesia. The problem is the high political effect, weak implementation of law rule and overloading. So that, Indonesia as a developing country should be had problem-solving to follow the steps of developed countries in the successful implementation of PBC.

\section{Conclusion}

PBC is a new potential idea to resolve the matters regarding conventional methods of contracting and has important potential to improved the maintenance and management of road infrastructure system. PBC is a potency system to be used up to the Indonesian national road management. Besides awarding a quality ensure through a sustainable road supervision and conservation, PBC also can be part of the solution to the complex problem of many aspects regarding social, technical, economical, environmental and political aspect with a long contract duration. Developed countries such as Australia and UK have implemented PBC successfully.

Sustainability of implementing PBC in Indonesia should pay attention to the main effort to success PBC, namely: long-term contract, a degree of freedom of the contractor in innovation, a balanced risk among owner and private sector, fairness reward and punishment, developing robust models to optimize maintenance strategies, increase database of specified the road network, maintain performance level before implementing long-term PBC. And must be able to resist the influence of high political effect, weak implementation of law rule 


\section{ACKNOWLEDGMENT}

This paper is part of my research disertation was financially supported by Ministry of High Education and Research, Republic of Indonesia, 2014 - 2017.

\section{REFERENCES}

[1] Nystrom.J, et al, 2014, "Degrees of freedom in Road Construction", Center for Transport Studies Stockholm, 2014

[2] Wirahadikusumah,R, et al, 2015, "Performance Based Contracting for Roads - Experiences of Australia and Indonesia", The 5th International Conference of Euro Asia Civil Engineering Forum(EACEF-5), ScienceDirect Procedia Engineering, 2015.

[3] Lenferink.S, et al (2013),"Towards sustainable infrastructure development through integrated contracts : Experiences with inclusiveness in Dutch infrastructure projects", International Journal of Project Management, Volume 31, Issue 4, May 2013, pages $615-627$.

[4] Sultana,Rahman,Chowdhury (2013),"A review of performance based maintenance of road infrastructure by contracting", International Journal of Productivity and Performance Management Vol. 62 No. 3, 2013 pp. 276-292 r Emerald Group Publishing Limited 17410401 DOI 10.1108/17410401311309186.

[5] Bueno. P.C, et al, 2013,'Road Infrastructure Design for Optimizing Sustainability”, European Investment Bank Institute, 2013.

[6] Jacopino. A, et al, 2015, "Deploying Performance-Based Contract for Outcomes", IACCM Australiasia Forum, Australian Government Department of Defence, 2015

[7] Alkhatairi et al (2014), "Performance Based Road Asset Management System, with a case study: Abu Dhabi", A thesis submitted to the Faculty of Graduate and Postdoctoral Affairs in partial fulfillment of the requirements for the degree of Doctor of Philosophy in Transportation Engineering Carleton University Ottawa, Ontario, 2014

[8] Loulakis.M.C, et al (2013), "Legal aspects of Performance-based specifications for highway construction and maintenance contracts", National Coperative Highway Research Program, July, 2013

[9] Gericke.B, et al (2014)," Review of Performance Based Contracting in the Road Sector-Phase 1", The International Bank for Reconstruction and Development/The World Bank, March, 2014.

[10] Pakkala.P (2013.B), “ Recent Developments in World Class Road Maintenance Contracts” , The XXVIII International Baltic Road Confrence, Lithuania, August, 2013.

[11] Faizal, N, (2013). "Dukungan Puslitbang Jalan dan Jembatan terhadap Kontrak Berbasis Kinerja (KBK)/Performance Base Contract (PBC) untuk mendukung Keselamatan dan Lingkungan Jalan”. Konferensi Regional Teknik Jalan ke-12, Bandung. 21-23 Oktober 2014. Himpunan Pengembangan Jalan Indonesia.

[12] Mulmi. AD, 2016,"Assessment of Performance Based Road Maintenance Practices in Nepal”, Open Journal of Civil Engineering, Scientific Research Publishing, 2016, 6, 225-241. http://dx.doi.org/10.4236/ojce.2016.62021

[13] Pike.A,et al (2014),"Evaluating the effectiveness of performance based pavement marking maintenance contracts in Texas", Texas A\&M Transportation Institute College Station, Texas 77843-3135, January, 2014

[14] Hughes, W and Khabiri,S (2013),"Performance-based contracting in the construction sector", School of Construction Management and Engineering, University of Reading,RG6 6AW,UK, 2013.

[15] Pakkala. P (2013.A), "Factors potentially influencing productivity in performance-based maintenance contracts (PBMC) - An International Study of Roads from Sweden", The $92^{\text {nd }}$ Annual Meeting of the Transportation Research Board, Washington DC, Januari, 2013

[16] Alozia.E, and Okezie, 2013,"A Case for Performance-Based Road Maintenance in Nigeria", The Technical Evening of the Nigerian Society of Engineers, A paper Presented: 29 August 2013

[17] Anwar.MF, et al (2016), "Implementation of Performance Based Contracting in Malaysia", International Review of Management and Marketing, 2016,6 (S8) 286-293.

\section{AUTHOR PROFILE}

Hanie Teki Tjendani, as a doctoral student in Civil Engineering at Institut Teknologi Sepuluh Nopember (ITS) Surabaya-Indonesia (2013 - Now), lecturer in the Civil Engineering Department, Universitas 17 Agustus 1945 Surabaya and as researcher in the field of Construction Management. I received Bachelor's degree in Civil Engineering, Udayana University Denpasar-Indonesia; magister of civil engineering in Universitas 17 Agustus 1945 Surabaya-Indonesia.

Nadjadji Anwar, as a professor and researcher in Civil Engineering in the field of water resources engineering and management at the Institut Teknologi Sepuluh Nopember (ITS) Surabaya-Indonesia. He received Bachelor's degree in Civil Engineering from Institut Teknologi Bandung (ITB), Bandung, Indonesia in 1979, Master of Science in Civil Engineering, Colorado State University, Fort Collins, Colorado, USA in 1982 and Doctor of Engineering in Civil and Environmental Engineering, Toyo University, Kawagoe-Shi, Saitama, Japan in 1998.

I Putu Artama Wiguna. as a associate professor and researcher ini Civil Engineering in the field of Construction Management at the Institut Teknologi Sepuluh Nopember (ITS) Surabaya - Indonesia, education backgroud : 1988-1993 Civil Engineering, Institut Teknologi Sepuluh Nopember Surabaya Indonesia; 19951997 Construction Management Institut Teknologi Sepuluh Nopember Surabaya Indonesia; 2002-2006, Construction Management, University of Newcastle upon Tyne,UK. 